УДК 624.012.45

DOI https://doi.org/10.32782/2664-0406.2020.37.8

\title{
Постернак 0.0.
}

к.т.н., доцент, доцент кафедри залізобетонних конструкцій і транспортних споруд, Одеська державна академія будівництва та архітектури, м. Одеса

\section{Кравченко С.A.}

к.т.н., доцент, доцент кафедри залізобетонних конструкцій і транспортних споруд, Одеська державна академія будівництва та архітектури, м. Одеса

\section{Агафонова І.П.}

викладач кафедри будівельної інженерії та економіки,

Бендерський політехнічний філіал Придністровського державного університету імені Т.Г. Шевченка, м. Бендери, Молдова

\section{Агаєва 0.A.}

к.т.н., асистент кафедри залізобетонних конструкцій і транспортних споруд, Одеська державна академія будівництва та архітектури, м. Одеса

\section{НЕСУЧА ЗДАТНІСТЬ ТА ДЕФОРМАТИВНІСТЬ ЗБІРНО-МОНОЛІТНИХ ТА МОНОЛІТНИХ ПЕРЕКРИТТІВ ІЗ КЕРАМЗИТОБЕТОНУ НА БАГАТОКОМПОНЕНТНОМУ В'ЯЖУЧОМУ}

\begin{abstract}
Анотація. Застосування легких бетонів на пористих заповнювачах для конструкцій будівель дає змогу збільшити прольоти й поверховість будинків, зменшити строки та знизити вартість будівництва.

Близько 20\% загальних витрат на будівнищтво нових будівель припадає на конструкціі перекриттів, тому важливим є вибір іх раціонального варіанта з погляду технологічності виготовлення, мічнісних характеристик і економічності. 3 чієї позицї актуальним є застосування збірно-монолітних та монолітних перекриттів.

У роботі здійснені дослідження несучої здатності й деформативності збірно-монолітного й монолітного перекриття з керамзитобетону на багатокомпонентному в'яжучому класу C 12/15 і важкого бетону класу C 20/25. Виконано зіставлення дослідних даних деформативності, тріщиностійкості і міцності зразка перекриття з результатами розрахунків за чинними нормами.

Проведений аналіз отриманих дослідних значень деформачій, переміщень і тріщин дає змогу зазначити, що в прочесі навантаження зразка чітко прослідковувалися описувані деформачійними моделями стадї його пружного й пружнопластичного деформування.

Несуча здатність зразка збірно-монолітного перекриття за розрахунком, в порівнянні з дослідними даними, була визначена з різнищею $1 \%$.

У разі нормативного навантаження ширина розкриття тріщин у монолітному перекритті становила 0,125 мм, а в збірно-монолітному - 0,1 мм, що менше встановленої нормами гранично припустимої ширини те =0,4 мм. У разі навантаження, еквівалентного руйнуючому, ширина розкриття тріщин не перевищувала граничних значень і становила 0,4 мм для монолітного перекриття й 0,3 мм - для збірно-монолітного перекриття.

Аналіз графіків «F-f» для збірно-монолітного й монолітного перекриття показав, що область діаграми, отриманої за результатами нормативних розрахунків, проходить майже паралельно дослідній діаграмі, розходження становлять у середньому $24 \%$ i $17 \%$.

Розроблені конструкцї збірно-монолітного й монолітного перекриття мають необхідну мічність, жорсткість і довговічність й можуть бути рекомендовані для застосування в будівництві малоповерхових суспільних і житлових будинків, а також при реконструкції.
\end{abstract}

Ключові слова: несуча здатність, деформативність, перекриття, легкий бетон. 
Залізобетонні конструкції з легких бетонів на пористих заповнювачах дають змогу збільшити прольоти й поверховість будинків, укрупнити монтажні елементи, використовувати більш прості з меншою вантажопідйомністю механізми для монтажу, підвищити продуктивність праці і якість будівництва, домогтися його прискорення, знизити вартість, що сприятливо не лише для малоповерхового будівництва.

Залізобетонні перекриття є одним із найбільш важливих конструктивних елементів житлових будинків. Вартість перекриттів у загальній вартості житлового будинку становить від 15 до 20\%, будівельні витрати праці на їх влаштування - до 25\%. Цей факт визначає важливість вибору раціонального варіанта застосовуваної конструкції перекриття 3 погляду технологічності виготовлення, міцнісних характеристик і економічності того або іншого проєкту.

Варто зазначити, що використання збірно-монолітних перекриттів приводить до значної економії матеріальних і енергоресурсів, зниження трудомісткості зведення шляхом спрощення арматурних робіт і скорочення або повного виключення робіт з монтажу й демонтажу опалубки.

Окрім того, застосування в процесі будівництва легких бетонів на пористих заповнювачах типу керамзиту забезпечує помітне зниження матеріалоємності й витрат на фундаменти, економію арматури і знижує вартість будівництва на 13-15\%.

Постановка проблеми. Використання легких бетонів у збірному й монолітному домобудівництві є досить актуальним завданням, оскільки передбачає вирішення багатьох актуальних завдань сучасного будівництва й одночасне вирішення екологічних, ресурсозберігаючих й економічних проблем за рахунок технологічних і техногенних відходів, які доцільно застосовувати в процесі виготовлення залізобетонних конструкцій.

Аналіз останніх досліджень. За останній час накопичилось багато досліджень несучої здатності й деформативності конструкцій із легких бетонів, які наведені в роботах
М.А. Ахматова, Є.М Бабича, Б.С. Комисаренко, А.І. Костюка, Р.Л. Маіляна, Л.П. Орентліхера, Н.Я. Співака, А.С. Столевича, В.Г. Суханова, О.Б. Пірадова та ін.

На сучасному рівні значний внесок у розвиток бетонів із використанням шлаків і золи зробили Ш.Т. Бабаєв, С.О. Висоцький, В.М. Горін, Л.Й. Дворкін, О.Л. Дворкін, С.В. Зінченко, А.Г. Зоткін, Камаль М.Р. Маді, М.Ю. Лещинський, Н.Р. Рузієв, О.В. Каляскін, В.Н. Ярмаковський та ін., але в основному ресурсозберігаючі питання через застосування промислових відходів під час виготовлення пористих заповнювачів і в'яжучих розглядаються для конструкцій із важкого бетону.

Мета роботи полягає в дослідженні несучої здатності й деформативності збірно-монолітного й монолітного перекриття з керамзитобетону на багатокомпонентному в’яжучому.

Дослідження проводилися на зразках збірно-монолітного й монолітного перекриття (рис. 1), виконаного з керамзитобетону на багатокомпонентного в'яжучого класу C 12/15іважкого бетону класу C 20/25(табл. 1).

У процесі випробувань навантаження прикладалося у вигляді 5 зосереджених сил в 1/6 прольоту. Рівні навантаження становили 5\% від розрахункового руйнівного навантаження до утворення тріщин і 10\% - після утворення тріщин. Навантаження на кожному етапі, крім першого, визначалися арифметичними обчисленнями за обмірюваною масою штучних вантажів.

У процесі випробувань вимірялися:

- прогини зразків у середині прольоту;

- поздовжні деформації арматури й бетону по бічних гранях основних зразків;

- значення навантажень тріщиноутворення, ширина розкриття тріщин;

- значення руйнівних навантажень.

Результати дослідження. Проведені дослідження передбачали зіставлення дослідних даних деформативності, тріщиностійкості й міцності зразка перекриття з результатами розрахунків за чинними нормами ДБН [1].

Розрахунок за чинними нормами [1] проводився до рівня навантаження, що становить $80 \%$ від максимального.

Таблиця 1. Фізико-механічні характеристики бетону

\begin{tabular}{|c|c|c|c|c|c|}
\hline Клас бетону & Вік, діб & $f$, МПа & $f_{c,}$ МПа & $f_{\text {cdd }}$ МПа & $E_{\text {, }}$ МПа \\
\hline $\mathrm{C} 12 / 15$ & 80 & 12,4 & 8,8 & 1,4 & 14800 \\
\hline $\mathrm{C} 20 / 25$ & 120 & 16,9 & 13,0 & 1,6 & 27800 \\
\hline
\end{tabular}


За даними показань тензорезисторів, наклеєних на бічних гранях елемента, можна говорити характер розподілу деформацій по висоті перетину як про лінійний із певним ступенем допущення (рис. 2).

Проведений аналіз отриманих дослідних значень деформацій, переміщень і тріщин дає змогу зазначити, що в процесі навантаження зразка чітко прослідковувалися описувані деформаційними моделями стадії його пружного й пружнопластичного деформування.

Для оцінки напружено-деформованого стану перетину дослідного зразка, що перебуває в зоні чистого вигину, будувалися залежності $\ll M-\varepsilon_{s}$. Критерієм вичерпання несучої здатності зразка перекриття з'явилося досягнення деформацій у поздовжній розтягнутій арматури граничних значень, як і в роботі [2].

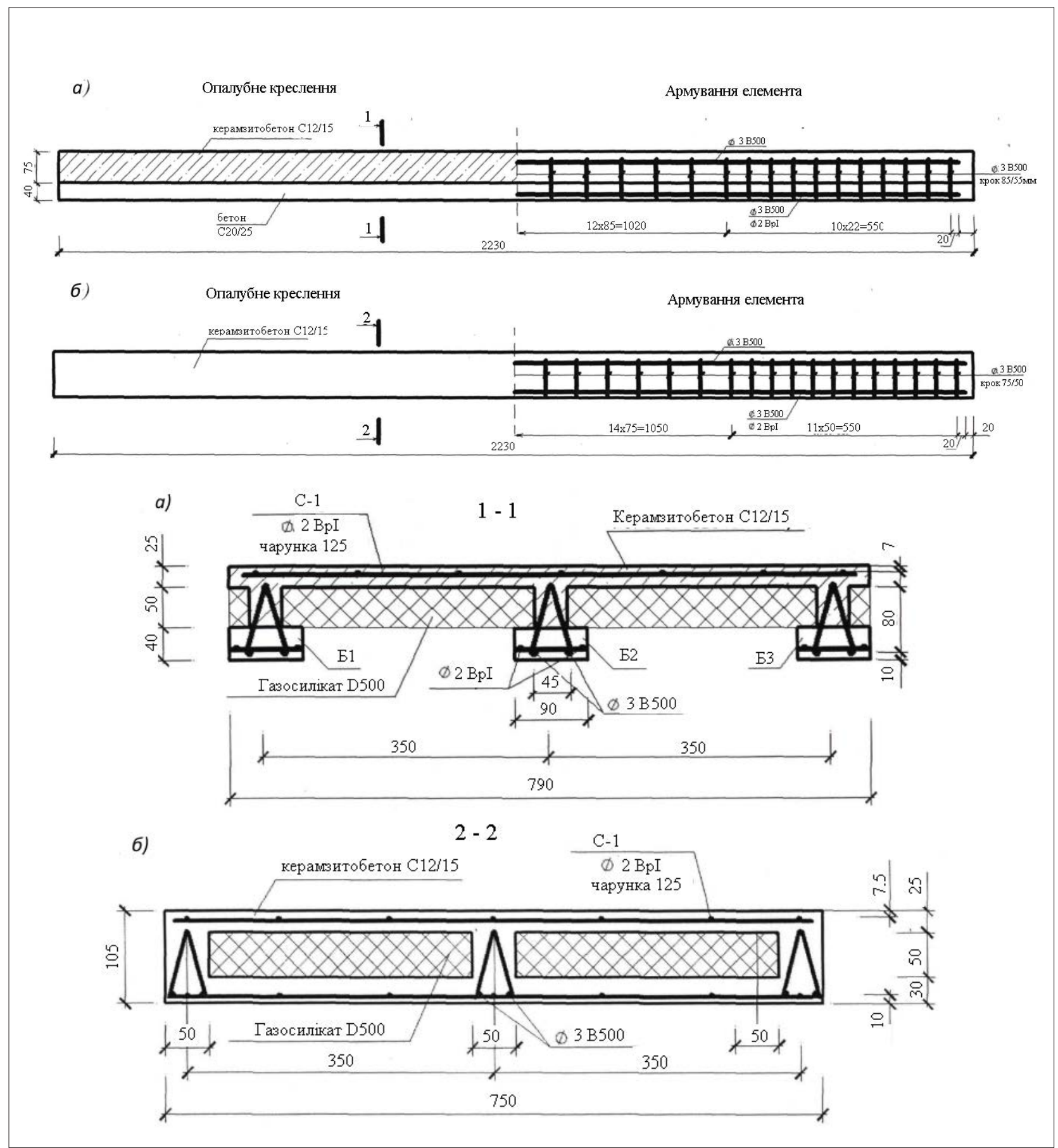

Рис. 1. Конструкція зразків збірно-монолітного перекриття: а - зразок збірно-монолітного перекриття; б - зразок монолітного перекриття 
Несуча здатність зразка збірно-монолітного перекриття (навантаження, при якому деформації в арматурі досягають граничних значень) була визначена з різницею порівняно 3 дослідними даними на 1\% (табл. 2).

Таблиця 2. Порівняння даних експериментальних досліджень щодо несучої здатності з теоретичним розрахунками

\begin{tabular}{|c|c|c|c|}
\hline \multirow{2}{*}{ Тип зразка } & \multirow{2}{*}{$\begin{array}{l}M^{\text {pocl }}, \\
\kappa \mathrm{H} \times \mathrm{M}\end{array}$} & \multicolumn{2}{|c|}{ ДБН В.2.6 - 2009} \\
\hline & & $M_{d}, \mathrm{KH} \times \mathrm{M}$ & $M_{d} / M^{\partial o c \imath}$ \\
\hline $\begin{array}{c}\text { Збірно- } \\
\text { монолітне } \\
\text { перекриття }\end{array}$ & 3,84 & 3,94 & 1,02 \\
\hline $\begin{array}{l}\text { Монолітне } \\
\text { перекриття }\end{array}$ & 3,99 & 3,76 & 0,94 \\
\hline
\end{tabular}

Під час проведення експериментальних досліджень були визначені характер утворення й розвитку тріщин (рис. 3,4 ), зміна відстані між тріщинами $s_{r}$ і висоти тріщин $h_{c r c}$ зі збільшенням навантаження.
У разі нормативного навантаження ширина розкриття тріщин у монолітному перекритті становила 0,125 мм, а в збірно-монолітному $-0,1$ мм, що суттєво менше встановленої нормами [1] гранично припустимої ширини $w_{k}=0,4$ мм.

${ }^{k} \mathrm{y}$ разі навантаження, еквівалентному руйнуючому, ширина розкриття тріщин не перевищувала граничних значень і становила 0,4 мм для монолітного перекриття й 0,3 мм для збірно-монолітного перекриття.

За обрисами графіків $« F-f »$ для збірно-монолітного й монолітного перекриття видно, що області діаграми, отриманої за результатами нормативних розрахунків (табл. 3), проходить майже паралельно дослідній діаграмі, при цьому недооцінюючи величину прогинів у розрахунковому перетині в середньому на $24 \%$ і $17 \%$.

Висновки. Отримані експериментальні дані про міцність, тріщиностійкість і деформативність зразків збірно-монолітного й монолітного перекриття 3 керамзитобетону на багатокомпонентному в'яжучому.

x)

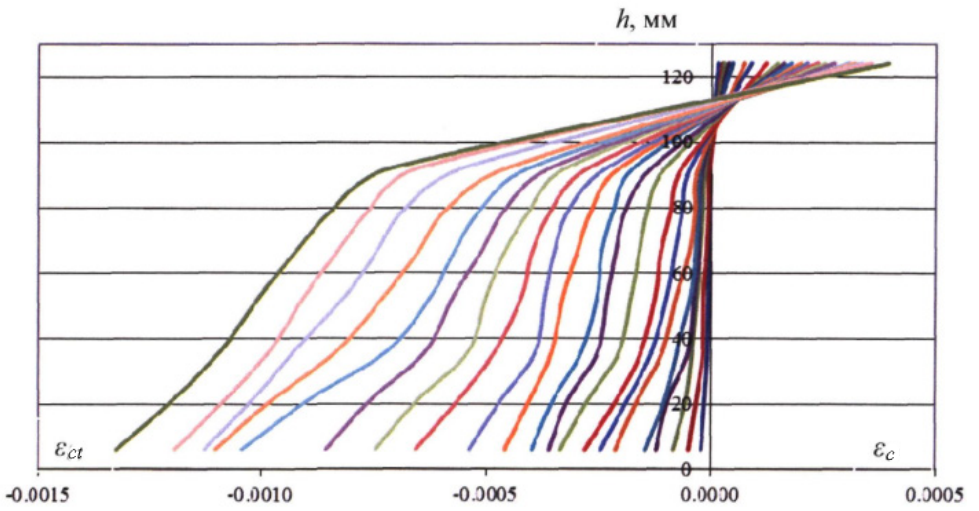

б)

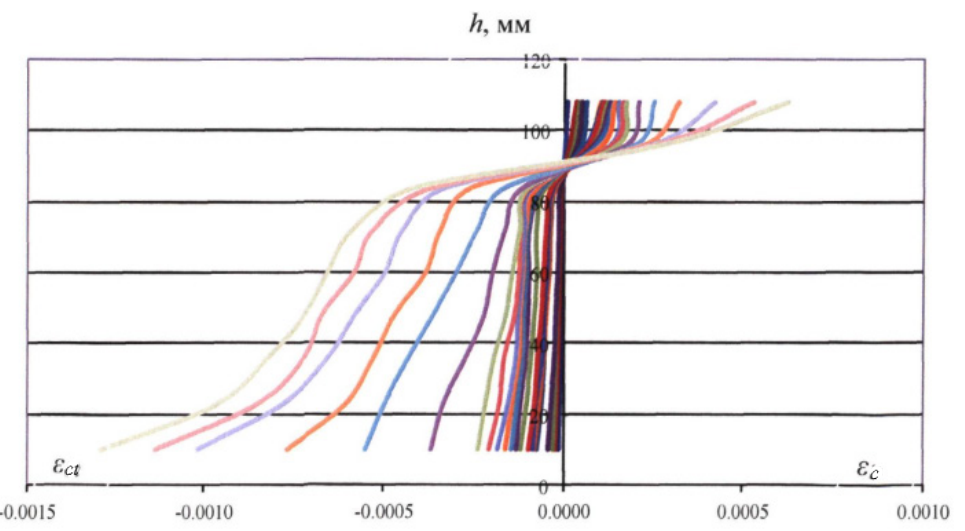

Рис. 2. Характер розподілу деформацій у бетоні за висотою перетину: a - збірно-монолітного перекриття; б - монолітного перекриття 


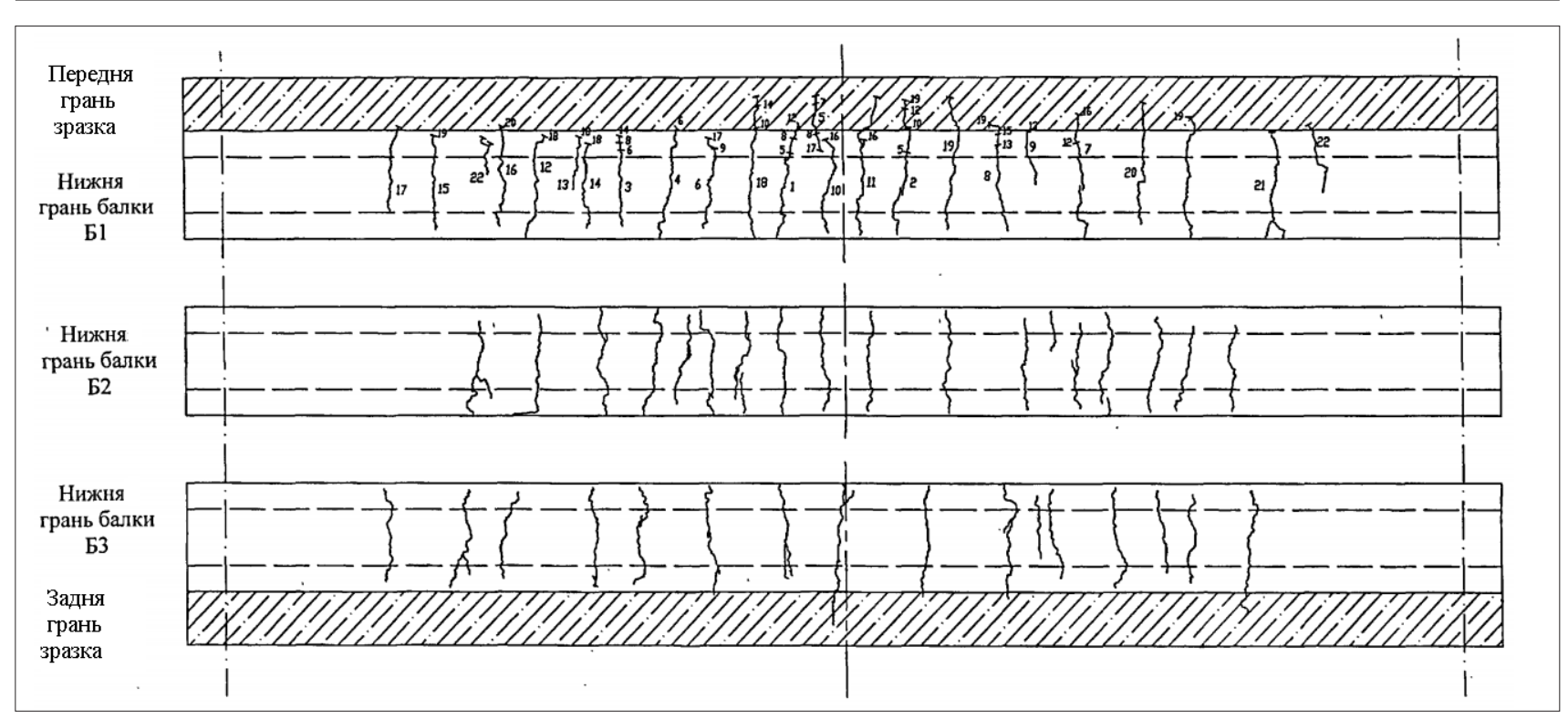

Рис. 3. Схема характерних тріщин за розгорненням дослідного зразка збірно-монолітного перекриття

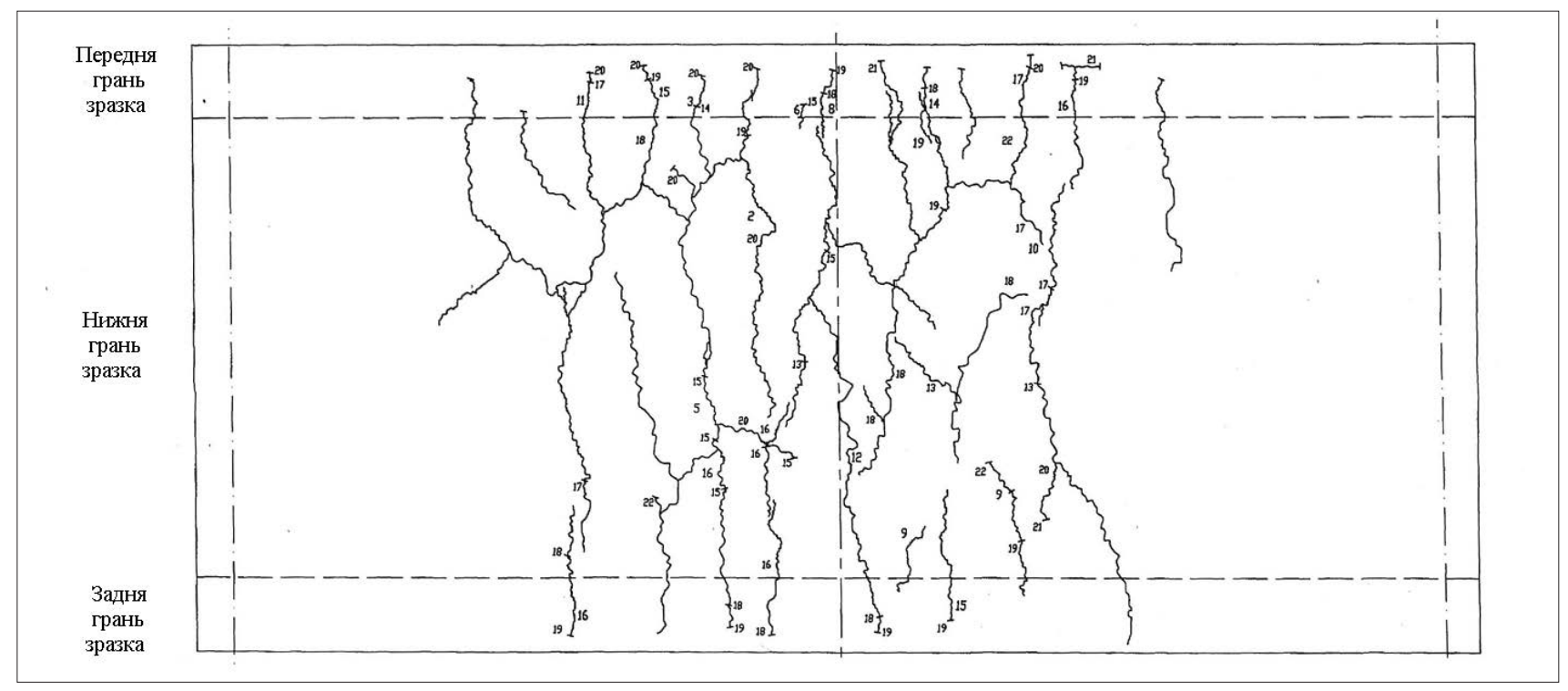

Рис. 4. Схема характерних тріщин за розгорненням дослідного зразка монолітного перекриття

Таблиця 3. Порівняння даних експериментальних досліджень за деформативністю з теоретичними розрахунками

\begin{tabular}{|c|c|c|c|c|}
\hline \multirow{2}{*}{ Тип зразка } & \multirow{2}{*}{$M_{i} / M_{d}$} & Прогин $f_{\text {досл }}$, мм & \multicolumn{2}{|c|}{ ДБН В.2.6-98:2009 } \\
\cline { 4 - 5 } & & & $f$, мм & $f / f_{\text {досл }}$ \\
\hline \multirow{3}{*}{ Збірно-монолітне перекриття } & 0,5 & 3,14 & 2,71 & 0,86 \\
\cline { 2 - 5 } & 0,6 & 5,49 & 4,11 & 0,75 \\
\cline { 2 - 5 } & 0,7 & 6,86 & 5,50 & 0,80 \\
\cline { 2 - 5 } & 0,8 & 8,02 & 2,13 & 0,86 \\
\hline \multirow{3}{*}{ Монолітне перекриття } & 0,5 & 1,54 & 3,93 & 1,38 \\
\cline { 2 - 5 } & 0,6 & 2,80 & 5,73 & 1,08 \\
\cline { 2 - 5 } & 0,7 & 5,30 & 7,53 & 0,95 \\
\cline { 2 - 5 } & 0,8 & 7,88 & & \\
\hline
\end{tabular}


Проаналізовано напружено-деформований стан, визначені експериментальні величини відносних поздовжніх деформацій бетону за висотою перетину, дослідні значення навантаження тріщиноутворення ширини розкриття тріщин, прогинів і величин руйнівного навантаження.

Проведені експериментальні дослідження зразків монолітного й збірно-монолітного перекриттів показали, що розроблені конструк- тивні рішення перекриттів мають значний запас жорсткості, який становить 42\% і 40\% відповідно.

Розроблені конструкції збірно-монолітного й монолітного перекриття мають необхідну міцність, жорсткість і довговічність й можуть бути рекомендовані для застосування в будівництві малоповерхових суспільних i житлових будинків, а також у процесі реконструкціі.

\title{
Jimepamypa
}

1. ДБН В.2.6 - 98: 2009. Бетонні та залізобетонні конструкції. Основні положення. Чинний від 01.06.2011. Київ : Мінрегіонбуд України, 2011. 71 с.

2. Смоляго Г.А. и др. Результаты экспериментальных исследований несущей способности, трещиностойкости и деформативности сборномонолитных и монолитных перекрытий. Известия Юго-Западного государственного университета. 2011. № 5-2. С. 105-109.

3. Смоляго Г.А., Дронова А.В. Несущая способность, трещиностойкость и деформативность сборно-монолитных и монолитных железобетонных перекрытий. Эффективные строительные конструкиии: теория u практика : сборник статей X Международной научно-технической конференции. Пенза : Приволжский Дом знаний, 2010. С. 48-51.

4. ДСТУ Б В.2.6-154:2010 "Бетонні та залізобетонні конструкції. Збірно-монолітні конструкції. Правила проектування. Чинний від 01.06.2011. Київ : Мінрегіонбуд України, 2011. 118 с.

\section{References}

1. DBN V.2.6 - 98: 2009. Betonni ta zalizobetonni konstrukcii'. Osnovni polozhennja. Chynnyj vid 01.06.2011. Kyi'v : Minregionbud Ukrai'ny, 2011. $71 \mathrm{s.}$

2. Smoljago G.A. Rezul'taty eksperimental'nykh issledovaniy nesushchey sposobnosti, treshchinostoykosti i deformativnosti sbornomonolitnykh i monolitnykh perekrytiy. Izvestiya Yugo-Zapadnogo gosudarstvennogo universiteta. 2011. № 5-2. S. 105-109.

3. Smoljago G.A., Dronova A.V. Nesushhaja sposobnost', treshhinostojkost' i deformativnost' sborno-monolitnyh i monolitnyh zhelezobetonnyh perekrytij. Jeffektionye stroitel'nye konstrukcii: teorija i praktika : sbornik statej $\mathrm{H}$ Mezhdunarodnoj nauchno-tehnicheskoj konferencii. Penza : Privolzhskij Dom znanij, 2010. S. 48-51.

4. DSTU B V.2.6-154:2010 "Betonni ta zalizobetonni konstrukcii". Zbirno-monolitni konstrukcii'. Pravyla proektuvannja. Chynnyj vid 01.06.2011. Kyi’v : Minregionbud Ukrai’ny, 2011. 118 s.

\section{BEARING STRENGTH AND DEFORMATION COLLAPSIBLE-MONOLITHIC AND MONOLITHIC SLABS FROM LIGHTWEIGHT CONCRETE ON A MULTICOMPONENT BINDING AGENT}

\begin{abstract}
Application of light concrete on porous fillers for the constructions of buildings allows to increase flights and houses number of storeys, decrease terms and reduce a building cost.

About 20\% general costs for the construction of new buildings are on the slab structures, so it is important to choose their rational variant from point of view of processability, strength characteristics and economy. From this position the application collapsible-monolithic and monolithic slabs is actual.

The work carried out researches of bearing capacity and deformability of collapsible-monolithic and monolithic slab from haydite concrete on multicomponent binder of class C12/15 and heavy concrete of class C20/25. Comparison of experimental information of deformability, crack resistance and durability of slab model with the results of calculations after operating norms is executed. The conducted analysis of the experimental values of deformations, moving and cracks, allows to mark that the stages of its elastic and elastic-plastic deformation described by the deformation models were clearly traced.

Bearing capacity of collapsible-monolithic slab model upon settlement, compared to experimental data, was determined with an error $1 \%$.
\end{abstract}


At the normative loading the crack opening width in the monolithic slab was 0,125 mm, and in the collapsible-monolithic 0,1 mm, that less than the maximum possible width established by the norms w $k=0,4 \mathrm{~mm}$. At loading equivalent to destroying, crack opening width did not exceed maximum values and made 0,4 $\mathrm{mm}$ for the monolithic slab and 0,3 $\mathrm{mm}$ for collapsible-monolithic slab.

Analysis of charts $\langle F-f »$ for collapsible-monolithic and monolithic slabs showed that the area of diagram, got as a result of normative calculations, runs almost parallel to the experimental diagram, divergences average $24 \%$ and $17 \%$.

Developed collapsible-monolithic and monolithic slab constructions have necessary durability and rigidity, and can be recommended for use in building of low-rise public and residential houses, and also in reconstruction.

Key words: Bearing capacity, deformations, slab, light weight concrete.

\section{Posternak A.A.}

PhD in Engineering, Associate Professor, Associate Professor at the Department of Reinforced Concrete Structures and Transport Facilities,

Odesa State Academy of Construction and Architecture, Odesa

\section{Kravchenko S.A.}

PhD in Engineering, Associate Professor, Associate Professor at the Department

of Reinforced Concrete Structures and Transport Facilities, Odesa State Academy of Construction and Architecture, Odesa

Agafonova I.P.

Teacher at the Department of Construction Engineering and Economics,

Bendery Polytechnic Branch of the Taras Shevchenko

Transnistria State University, Bendery, Moldova

Ahaieva O.A.

$\mathrm{PhD}$ in Engineering, Assistant at the Department of Reinforced Concrete Structures

and Transport Facilities,

Odesa State Academy of Construction and Architecture, Odesa 